However, my amusement ended abruptly as I though to myself, "Now who is going to believe this?" I phoned my brother Guy, who, after I did some convincing, said he would come over. However, he decided to run a few errands on the way, and did not arrive until a full hour later, shaking his head at my enthusiastic description of what had happened. Of course, I had not seen the wren since our phone call, but by now there were numerous birds moving through the yard so I convinced him to stay and check things out.

Patiently, we sat out in the heat swilling Kool-Aid like a couple of seven-year-olds until, remarkably, the Rock Wren suddenly reappeared
90 minutes after the original sighting! It was exploring the dead branch of a large elm that hangs over the balcony. We were directly beneath the bird and watched as it worked its way down the branch, upside down in a nuthatch-like fashion. When it reached the main trunk of the tree, the wren flew away, this time for good.

Since there is an obvious lack of Rock Wren habitat in Saskatoon, I suppose the stucco-coated house was the closest thing to a rocky outcropping the bird could find. My suggestion is, if you live in or near one of these houses, keep your eyes open for the elusive urban Rock Wren.

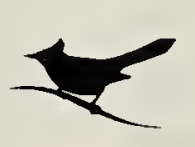

\title{
MOUNTAIN BLUEBIRD NESTS IN CLOTHES DRYER VENT
}

W.H. KOONZ, Manitoba Department of Natural Resources, 1495 St. James Street, Winnipeg, Manitoba. R3H OW9

On 14 and 15 June 1993, I stayed at a government bunkhouse in Aessippi Provincial Park, northwest of Riding Mountain National Park. I found Mountain Bluebirds nesting in a clothes dryer vent and in a bird house on a power pole some $30 \mathrm{~m}$ in front of the building.

The dryer vent was an aluminum tube $9 \mathrm{~cm}$ in diameter and $60 \mathrm{~cm}$ long, attached to a semitransparent plastic tube which led to the dryer. The plastic flap covering the outside end of the vent had fallen off leaving an entrance hole $30 \mathrm{~cm}$ above ground. Nesting material filled the plastic tube toward the dryer end 15 $\mathrm{cm}$ from where it intersected with the aluminum pipe. Three nestlings nested on shallow material up against the nest bulk.

No one had stayed at the bunkhouse until 7 June and the dryer had not been used in 1993. Despite an area cleanup on 15 June (shrubs trimmed and grass cut), the adult birds continued to attend their young. 
The room where the dryer sat lacked windows, and because the plastic tube was semitransparent, on a bright day it was possible to see the adults feeding their young. I removed the plastic pipe from the aluminum tube for a short period on 15 June to study the young and the nesting material. The hatchlings were about three days from fledging at that time.

It was not surprising to find a holenesting bird adapting to a man-made structure but it was noteworthy that the opening was no more that $30 \mathrm{~cm}$ above the ground and the nest was at least $65 \mathrm{~cm}$ inside the opening.

Criddle commented on the Mountain Bluebird adaptability as follows: "The male bird is an extreme optimist and nearly any hole meets with his approval. The male actively seeks out holes for future nests and pokes his head into various places." Bent states, "Almost any cavity and almost any location seems to suit them. They have been recorded nesting in stream banks (old kingfisher nest chambers) and in stubs nearly nine metres above the ground. Cliff crevices, rocks, and almost any cavity are possible nesting sites, especially if near human habitations and ranches. They also have been known to take over Cliff Swallow nests, chipmunk holes and they will nest inside buildings." ${ }^{1}$ In the Okanagan valley they have nested in many strange locations including an active sawmill wall, an abandoned electrical generator radiator, and a cattle guard that was driven over continually. ${ }^{2}$

In southwestern Manitoba, the Mountain Bluebird is largely confined to using nest boxes, but when boxes are not availabie they can adapt to a number of alternative sites.

1. BENT, A.C. 1949. Life histories of North American thrushes, kinglets, and their allies. Smithsonian Institution. U.S. National Museum Bull. 196. Library of Congress. New York. 452 pp.

2. CANNINGS, ROBERT A., R.J. CANNINGS, and S.G. CANNINGS. 1987. Birds of the Okanagan Valley, British Columbia. Royal British Columbia Museum, B.C. 420 pp.

3. CRIDDLE, N. 1927. Habits of the Mountain Bluebird in Manitoba. Can. Field-Nat. 41:40-44.

"Everybody knows," one naturalist has written, "that the autumn landscape in the north woods is the land, plus a red maple, plus a ruffed grouse. In terms of conventional physics, the grouse represents only a millionth of either the mass or the energy of an acre. Yet subtract the grouse and the whole thing is dead." Aldo Leopold, 1949. A Sand County Almanac. Oxford. 